\title{
Financial Studies of The Development Project of Belawan Access Channel at PT. Pelindo I (Persero)
}

\author{
Listiani Nurul Huda \\ Department of Industrial Engineering \\ Engineering Faculty of the University of North Sumatera \\ Medan, Indonesia \\ lnurulh@gmail.com
}

\begin{abstract}
Abstrak-Geographical condition of Indonesia that is dominated by sea led Indonesia to desperate need of the sea transportation management to meet its operational needs. PT. Pelindo I is a company that has the authority to manage the port in North Sumatra and its surrounding areas. Belawan's current access channel depth is between $\mathbf{- 7} \mathrm{s} / \mathrm{d} \mathbf{- 9} \mathrm{mLWS}$. Ships that can directly enter the port area is a vessel with a draft of (hull) by 8 meters, while the larger vessels have to wait for high tide. Meanwhile, the ASEAN Economic Community policy and has been implemented since December 2015. Thus the deepening of the access channel to accommodate larger ships in order to expedite the process of marine transport is necessary. The purpose of this study was to assess the financial feasibility of the port plot development investments and facilities in the Port of Belawan and BICT. A financial review conducted by the parameter IRR and PI. Economic benefit analysis was also conducted to analyze the differences in the conditions 'project' and without the project. Having obtained the value of benefits and costs of economic and financial investment, a sensitivity test is carried out to test the sensitivity of investment to the uncertainty. The results of the analysis of the economic benefits of providing value EIRRs of $23.04 \%$ and PI worth of 3.83 with a discount factor of $12 \%$. The results of the financial analysis of investment with the level of discount factor of $15 \%$ was obtained, namely $31.01 \%$ IRR and PI of 2.75 , which means the investment is feasible.
\end{abstract}

Keywords-Ports of Belawan; BICT; Investment Criteria; Sensitivity Analysis; Financials

\section{INTRODUCTION}

PT. Pelindo I is a company that is authorized to manage the port in North Sumatera and the surrounding area. Some of of them are the Port of Belawan and BICT (Belawan International Container Terminal) that are using the same access channel that is Belawan Access Channel. The current depth of the access channel is ranged between $-7 \mathrm{~s} / \mathrm{d}-9$ mLWS (minus seven $\mathrm{s} / \mathrm{d}$ minus nine meters Lower Water Spring) in the the lowest state and the highest height of the tide is 3.41 meters [1]. This depth can only accommodate ships with a draft of 8 meters or smaller. While the ship with a draft greater than 8 meters had to wait for ocean tides that are only available at the most 12 hours in a day [2].
It is even more alarming because in December 2015, the AEC policy that frees import duties for countries that are members of ASEAN has been accomplished. This policy will make the price of imported products be approximately the same or even cheaper than local products. These conditions will make local products less competitive than imported products and will lead to reduced levels of the Indonesian economy. Moreover, the condition of Indonesian domestic marine logistics costs are relatively high compare to international maritime logistics costs [3]. The cost comparison of Indonesian and international maritime logistics shown in Figure 1.

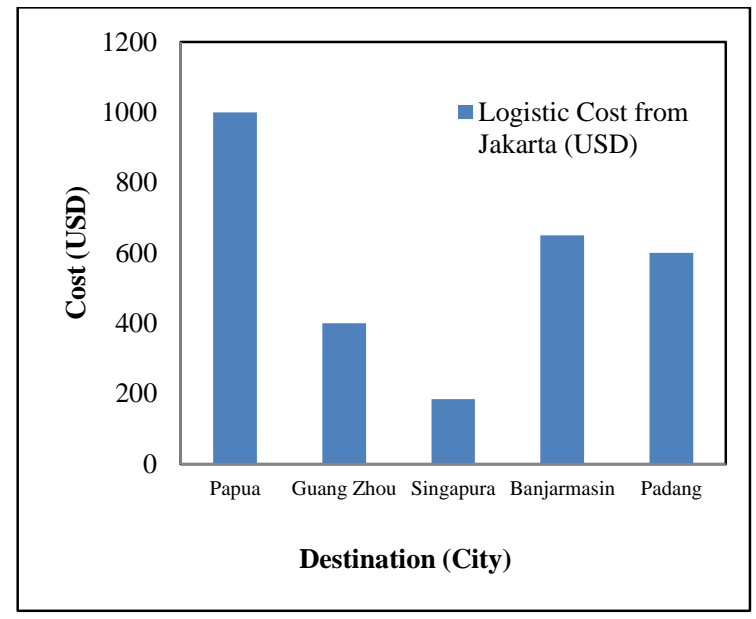

Figure 1. Marine Logistics Costs

From Figure 1 we can see that the cost of logistics from Jakarta to Padang which were located much closer is much more expensive than the Jakarta to Guang Zhou which is located in China. The cause of this problem one of them is the limited depth of the port access channel in Indonesia, which average less than $9 \mathrm{~m}$-LWS and can only accommodate small boats. As has been demonstrated in previous studies [4] and [5], that the bigger the vessel the less the cost required for a ship trip. Therefore, Pelindo I plan to deepen the access channel which is accompanied by improvement of port facilities to accommodate the increased demand for services that is going to happen in the future. 
This research will be doing investment decisions in improving service capacity and then test the project's feasibility based on the financial parameters that are IRR (Internal Rate of Return) and PI (Profitability Index). Comparisons between the current conditions and conditions after development projects will also be conducted to determine the value of the economic benefits of the project as seen from the parameter EIRR (Economic Internal Rate of Return) and PI. It also will test the sensitivity of the project to analyze the results of financial and economic parameters as done in the previous study in [2], [6], [7], [8] and [9].

\section{METHODOLOGY}

The study was conducted at the Port of Belawan and BICT that located at Suar Street No. 1, Belawan, North Sumatra. The object of research is Belawan access channel along the \pm 1300 miles. Data used in the study includes data flow of ships and goods, facilities loading and unloading, as well as port services tariff. The data was obtained by means of documentary studies and interviews. Especially for the data flow of ships and goods used actual historical census data flow of ships and goods in the period 2009-2015. This historical data will be projected with statistical software Minitab 17 and Ms. Excel for a period of 30 years (project's period). Forecasting results will be used to determine the company's revenue in the future by multiplying each frequency usage related services at the prevailing rate. Besides that, forecasting results are also used to calculate the investment needs of the facility in the future. These calculations are used to determine the required number of loading and unloading facilities such as cranes, conveyors, loading point and loading-unloading labor, as well as additional quay length. After that productivity of the port after the deepening of the access channel will be obtained. The value is expressed in port productivity BOR (Berth Occupancy Ratio). Berth Occupancy Ratio is the ratio between the amounts of usage of each dock available at the time available. The formula for calculating the BOR is as follows [10]:

$B O R=\frac{(n \text { Call } x(\bar{x} L O A+5) x(\bar{x} \text { Berthing Time })}{\text { Quay Length } x \text { Available Time in } 1 \text { Period }} \times 100 \%$

BOR value suggested by the Board of the Port Authority of Indonesia was $70 \%$. This value indicates that the activities of loading and unloading in ports still can run smoothly without any significant congestion.

Having obtained the unit amounts facilities necessary, these costs will be added to the cost of dredging and maintenance to get the annual flow of investment costs. Operating cost data obtained by simulating the actual data in 2014 are multiplied by random numbers and are assumed to increase $20 \%$ every five years. After the revenue and operating costs are known, then the investment will be measured based on investment criteria parameters to be used are [11]:
1. Internal Rate of Return(IRR) is a discount rate that results in net present value equal to 0 (zero). Therefore, if the IRR calculation result is greater than the Social Opportunity Cost of Capital (SOCC) the project is feasible. If IRR is the same as the SOCC means the return of principal and under SOCC then the project is not feasible.

$$
I R R=i_{1}+\frac{N P V_{1}}{\left(N P V_{1}-N P V_{2}\right)}\left(i_{2}-i_{1}\right)
$$

Where:

$i_{1}=$ Discount factor that results in $N P V_{1}$

$i_{2}=$ Discount factor that results in $N P V_{2}$

2. Net Present Value (NPV) is the discounted net benefits of using the Social Opportunity Cost of Capital (SOCC) as the discount factor. Investment is considered feasible if NPV> 0.

$$
N P V=\sum_{i=1}^{n} \bar{B}_{i}-\bar{C}_{i}=\sum_{i=1}^{n} N \bar{B}_{i}
$$

Where:

$\mathrm{NB}=$ Net Benefit $=$ Benefit - Cost

$\mathrm{B}=$ Benefit which has been discounted

C = cost which has been discounted

$\mathrm{i} \quad=$ Discount Factor

$\mathrm{n} \quad=$ Year (time)

3. Profitability Index (PI) is the ratio of net cash flow to the present value of the initial investment cost (initial outlay).

$$
P I=\frac{\sum_{i}^{n} \frac{P n}{(1+i)^{n}}}{I_{o}} \text { or } P I=\frac{P V C F}{I_{o}} \ldots
$$

Where:

$\mathrm{P}=$ net cash flow

$\mathrm{I}=$ discount factor

$\mathrm{n}=$ period

Io $=$ the initial investment cost

Criteria for deciding as follows:

a. PI $>1$, the proposed investment /project received

b. PI $<1$, then the investment proposal /project rejected

Investment criteria tests are conducted for financial and economic analysis. The financial analysis is the analysis conducted to estimate the actual costs and cash flow from the perspective of those who carry out the project and calculate the financial benefits to determine the feasibility of the project. While the economic feasibility is used to measure the costs and benefits from the perspective of the general community (neighborhood) then calculates economic profit to decide the feasibility of the project. Investment criteria used in the assessment of the feasibility of both types are the same except for the IRR and NPV on financial feasibility renamed EIRR (Economic Internal Rate of Return) and ENPV (Economic Net Present Value) on the economic viability [12].

In this research, economic analysis done by using the difference in the benefits received by the port and port services users (ship owners) with the plot development. In this case, the variable that is calculated is reduced waiting times for large vessels (above 8.5 meters draft) as a result of the deepened access channel. While 
operating costs used in the calculation of operational costs of financial analysis that has been reduced by taxes.

Having obtained the investment criteria to test the sensitivity analysis with 6 (six) scenarios to see investments resistance to changing conditions.

\section{RESULT AND DISCUSSION}

\section{A. Productivity Studies}

Studies conducted on the productivity level of ships services performed by the port in the annual period. The actual data traffic ports of Belawan and BICT showed in Table 1.

Table 1. Data Traffic Belawan and BICT 2009-2015

\begin{tabular}{|c|c|c|c|c|c|c|c|c|c|}
\hline \multirow{2}{*}{ No. } & \multirow{2}{*}{ commentary } & \multirow{2}{*}{ unit } & \multicolumn{7}{|c|}{ Year } \\
\hline & & & 2009 & 2010 & 2011 & 2012 & 2013 & 2014 & 2015 \\
\hline \multicolumn{10}{|c|}{ Belawan } \\
\hline A & Ship visits & call & 3389 & 3190 & 2871 & 2751 & 2926 & 3560 & 3723 \\
\hline B & Goods traffic & $\begin{array}{c}\cdot 000 \\
\text { Tons }\end{array}$ & 12.289 & 12.890 & 12.795 & 12.060 & 12.508 & 11.751 & 9.807 \\
\hline \multicolumn{10}{|c|}{ PORT BICT } \\
\hline A. & t & call & 479 & 472 & 442 & 493 & 546 & 484 & 500 \\
\hline \multirow[t]{6}{*}{ B. } & Export Import & & & & & & & & \\
\hline & 1. Based on the Box & & & & & & & & \\
\hline & a. Import & Box & 126.529 & 139.687 & 155.697 & \begin{tabular}{|l|}
159.699 \\
\end{tabular} & 167.303 & \begin{tabular}{|l|}
169.617 \\
\end{tabular} & 157.43 \\
\hline & b. Export & Box & 134.068 & 147.263 & 164.455 & \begin{tabular}{|l|}
169.879 \\
\end{tabular} & 189.847 & \begin{tabular}{|l|}
191.355 \\
\end{tabular} & 184.331 \\
\hline & c. Transhipment & Box & 2 & 1 & - & - & & - & - \\
\hline & amount & Box & 260.599 & \begin{tabular}{|l|}
286.951 \\
\end{tabular} & 320.152 & \begin{tabular}{|l|}
329.578 \\
\end{tabular} & 357.15 & \begin{tabular}{|l|}
360.972 \\
\end{tabular} & 342.761 \\
\hline
\end{tabular}

Based on Table 1 shows that the Port of Belawan traffic has decreased. This is caused by the global crisis which led to the decline of local and international trading activities. Based on Table 1projections was conducted using the software Minitab 17 with regression forecasting method as was done in previous studies [13]. The variables used in this forecast are the gross domestic product per capita purchasing power equilibrium of Indonesia (GDP), the number of Indonesian population, inflation, and the total commodity. Each regression models forecasting commodity are shown in Table 2.

Table 2. Regression Forecasting Model

\begin{tabular}{|c|c|c|c|}
\hline No. & $\begin{array}{c}\text { Dependent } \\
\text { variable }\end{array}$ & Regression Model & R2 \\
\hline 1 & BBM & $8521899-749.4$ GDP & $93.07 \%$ \\
\hline 2 & Liquid bulk & $-113199+375+88000$ GDP Inflation & $66.15 \%$ \\
\hline 3 & Dry bulk & $-7511499+137961+0.04504$ Indonesian Population Inflation & $95.63 \%$ \\
\hline 4 & Animal & $-109607+4214+11.68$ GDP Inflation & $66.99 \%$ \\
\hline 5 & $\begin{array}{c}\text { General } \\
\text { cargo }\end{array}$ & $34142107-0.1299$ Indonesian Population & $71.19 \%$ \\
\hline 6 & Foreign ships & $\begin{array}{c}2729-0.000128 \text { Total (BBM + Bulk Dry +Liquid Bulk + Animal + } \\
\text { General cargo) }\end{array}$ & $76.20 \%$ \\
\hline 7 & Local ship & $\begin{array}{c}\text { 3188 - 0.000098 Total (BBM + Dry Bulk + Liquid Bulk + Animal + } \\
\text { General cargo) }\end{array}$ & $72.57 \%$ \\
\hline 8 & Import & $13066+15: 24$ GDP & $69.31 \%$ \\
\hline 9 & Export & $-56381+24.40$ GDP & $87.89 \%$ \\
\hline 10 & Call & $356+0.000409$ Total (Imports + Exports) & $77.88 \%$ \\
\hline
\end{tabular}

After forecasting model is known, then used the app Ms. Excel to get the value of forecasting results over the next 30 years. This value is the result of the desired projection. The result of the growth projections of ships in 2016-2045 are shown in Table 3.
Table 3. Results Projected Traffic Belawan

\begin{tabular}{|c|c|c|c|c|c|}
\hline Factor & unit & $\mathbf{2 0 1 5}$ & $\mathbf{2 0 2 6}$ & $\mathbf{2 0 3 6}$ & $\mathbf{2 0 4 6}$ \\
\hline \multicolumn{7}{|c|}{ Belawan } \\
\hline Total Demand & tonne & $8,708,215$ & $13,962,643$ & $16,682,373$ & $20,346,677$ \\
\hline Ships Log & call & 3,672 & 2.761 & 2.147 & 1,319 \\
\hline On average Cargo Ship & Ton / Ship & 2.372 & 5.058 & 7.771 & 15.426 \\
\hline Required Quay Length & meter & $3,167.96$ & $3,167.96$ & $3,167.96$ & $3,167.96$ \\
\hline BOR & $\%$ & 33.98 & 39.72 & 51.54 & 60.90 \\
\hline \multicolumn{7}{|c|}{ BICT T } \\
\hline Total Demand & Box & 342.761 & 652.583 & 898.608 & $1,234,469$ \\
\hline Ships Log & call & 500 & 623 & 742 & 861 \\
\hline On Average Cargo Ship & Box / boat & 686 & 1047 & 1211 & 1434 \\
\hline Required Quay Length & meter & 550 & 900 & 900 & 900 \\
\hline BOR & $\%$ & 33.72 & 43.41 & 60.73 & 68.71 \\
\hline
\end{tabular}

Table 2 shows that the productivity of the port was assessed using parameters Berth Occupancy Ratio (BOR). Seen that with the deepening of the access channel and the addition of port facilities, port productivity is still included in good categories that is below the standard of 70\%. [14]

\section{B. Assessment of Economic Benefits of Investment Projects}

Investments benefits are calculated in research are the economic benefits of the project. The economic benefits are calculated in order to see the difference between the condition of 'project' and 'without project'. Benefits of the investment come from two aspects: the direct benefits (benefits gained by the harbor) and indirect benefits (benefits for users of port services). These benefits occur because of the reduction in vessel waiting costs due to lack of access channel heights for large vessels to be anchored to the port. This waiting time also leads to opportunity cost for shipowners and port management.

Opportunity cost for port management is calculated by the loss of income because the idle time of the piers when ships cannot enter on time. Meanwhile, the opportunity cost for shipowners is calculated by the additional cost for maintaining the ship condition while waiting for required high tide and the loss of income that could earn while waiting.

The project's cost-source in project's economic benefits derived from the financial cost has been reduced by the tax [12]. This value is the result of the conversion of financial cost has been reduced by the value of the income tax and value added tax. The result of the calculation of investment criteria shows that investment is economically viable. Results of the investment criteria of project's economic benefit shown in Table 4.

Table 4. Test Result of Investment Criteria of Project Economic Benefit

\begin{tabular}{|l|l|l|}
\hline Df & IRR & PI \\
\hline $12 \%$ & $23.04 \%$ & 3.83 \\
\hline $15 \%$ & $23.04 \%$ & 1.97 \\
\hline $17 \%$ & $23.04 \%$ & 1.20 \\
\hline
\end{tabular}

The result shows that the project is economically feasible based on the value of IRR and PI. This result is eligible enough if compared on the feasibility study of Port of $\mathrm{Tg}$. Bulupandan and Socah which respectively only can get the 
value of EIRR of $17.2 \%$ and $15.4 \%$ and PI of 1.44 and 1.25 with discount factor at $15 \%$ in [2] and feasibility study of Port in Baubau with EIRR of $24 \%$ and PI of 2.5 with discount factor $12 \%$ [8].

Benefits of the project were also tested with a sensitivity analysis to see the effect of uncertainty on the results of calculations of project benefits. Methods of sensitivity analysis in this study using the changes to the costs and benefits as has been done in research Investment Feasibility Studies Procurement of Equipment PT. Pelabuhan Indonesia IV (Persero) in Makassar [15]. The results of the sensitivity analysis of project benefits shown in Table 5 .

Table 5. Sensitivity Analysis Project Benefits

\begin{tabular}{|c|c|c|c|c|}
\hline \multirow{2}{*}{ No. } & parameter Changes & \multicolumn{3}{|c|}{ df $=\mathbf{1 2 \%}$} \\
\cline { 3 - 5 } & & IRR & NPV & PI \\
\hline 1 & Costs up 20\%, benefit fixed & $20.74 \%$ & $504,222,890$ & 3.23 \\
\hline 2 & Costs fixed, benefits down 20\% & $18.83 \%$ & $353,742,110$ & 2.27 \\
\hline 3 & Costs up 20\%, benefit down 20\% & $16.73 \%$ & $261,482,376$ & 1.68 \\
\hline 4 & Costs up 30\%, benefit fixed & $19.69 \%$ & $458,093,023$ & 2.94 \\
\hline 5 & Cost fixed, benefits down 30\% & $16.63 \%$ & $232,371,853$ & 1.49 \\
\hline 6 & Costs up 30\%, benefits down 30\% & $13.71 \%$ & $93,982,253$ & 1.00 \\
\hline
\end{tabular}

Sensitivity test showed that the project would remain viable when costs up reach or exceed $30 \%$ and benefits down does not reach or exceed $30 \%$. This result can also be considered good since other research mostly only get the positive value when the changes do not exceed $20 \%$ such as [2] \& [8].

\section{Study of Investment Criteria}

In calculating the investment criteria needed some information that is big data investments, operational costs, and the value of investment benefits. Investment data are shown in Table 6. This data was obtained through the calculation of investment needs in the future with the data flow forecasting and ship goods in 2017-2046. Cost per unit at cost components derived from the feasibility study development of the Port of Surabaya.[2]

Table 6. Investment Data

\begin{tabular}{|l|l|c|c|c|c|c|}
\hline No. & \multicolumn{1}{|c|}{ Cost component } & Unit & $\begin{array}{c}\text { Total } \\
\text { Physical }\end{array}$ & $\begin{array}{c}\text { Unit } \\
\text { Cost } \\
\text { (USD) }\end{array}$ & $\begin{array}{c}\text { Total } \\
\text { Cost } \\
\text { (USD) }\end{array}$ & $\begin{array}{c}\text { Depreciation } \\
\text { Value } \\
\text { (USD) }\end{array}$ \\
\hline I & Physical investment & & & & & \\
\hline 1 & Dredging & & & & & \\
\hline & a. Capital Dredging 2.7 $\mathrm{mLWS}$ & $\mathrm{m}^{3}$ & $3,861,000$ & 5 & $19,305,000$ & 643.500 \\
\hline & b. Shoal Disposal & $\mathrm{m} 3$ & 579.150 & 7 & $4,054,050$ & 135.135 \\
\hline & c. Maintenance Dredging & $\mathrm{m} 3$ & $3,983,088$ & 1.66 & $6,611,926$ & 220.398 \\
\hline 2 & Tools \& Machines & & & & & \\
\hline & a. Container Crane (2016) & Unit & 1 & $6,025,000$ & $6,025,000$ & 108.450 \\
\hline & b. Mobile Crane (2016) & Unit & 3 & 186.156 & 558.468 & 10.052 \\
\hline 3 & Pier construction of BICT & $\mathrm{m} 2$ & 350 & 248.572 & $87,000,200$ & $1,740,004$ \\
\hline II & Non Physical investment & & & & & \\
\hline & $\begin{array}{l}\text { a. } \text { Design \& Engineering } \\
\text { Consultants }\end{array}$ & - & - & $20,000,000$ & $20,000,000$ & 400.000 \\
\hline & $\begin{array}{l}\text { b. } \text { Administration } \\
\text { Concessions }\end{array}$ & - & - & $12,355,464$ & $12,355,464$ & 247.109 \\
\hline & c. Cost of Feasibility Study & - & - & 11.169 & 11.169 & 223 \\
\hline III & Tax & - & - & $11 \% \times$ Total \\
Cost & $17,151,341$ & \\
\hline & amount & & & & $\mathbf{1 7 3 , 0 7 2 , 6 1 8}$ & $\mathbf{2 , 8 5 7 , 5 3 9}$ \\
\hline
\end{tabular}

Data of benefits value and operating costs are shown in Table 7. Data benefits and operating costs have been modified, namely an increased rate of $20 \%$ every 5 years to benefit and increase annual operating costs by $20 \%$ every 5 years. Table 7 is the calculation of the cash flow of investment in 2017-2046.

Table 7. Investing Cash Flows (in thousand USD)

\begin{tabular}{|r|l|r|r|r|r|r|}
\hline \multirow{2}{*}{$\begin{array}{c}\text { No } \\
\text { Component }\end{array}$} & \multicolumn{5}{|c|}{ to-year } \\
\cline { 2 - 7 } & \multicolumn{1}{|c|}{$\mathbf{0}$} & \multicolumn{1}{|c|}{$\mathbf{1}$} & \multicolumn{1}{c|}{$\mathbf{1 0}$} & \multicolumn{1}{c|}{$\mathbf{3 0}$} \\
\hline A & Cash In Flow & & & & & \\
\hline & 1. Total Revenue & & 87.498 & 151.160 & 267.141 & 423.348 \\
\hline 2. Investment & 173.073 & & & & \\
\hline & Total Inflows & 173.073 & 87.498 & 151.160 & 267.141 & 423.348 \\
\hline B & Cash Out Flow & & & & & \\
\hline & 1. Investment Cost & 173.073 & & & & \\
\hline & 2. Salary & & 15.168 & 20.203 & 26.938 & 32.459 \\
\hline & 3. Materials & & 8.891 & 11.416 & 14.510 & 17.782 \\
\hline & 4. Maintenance & & 5.527 & 7.561 & 9.108 & 11.275 \\
\hline & 5. Administration & & 482 & 677 & 772 & 994 \\
\hline & 6. Depreciation & & 9.833 & 11.504 & 9.833 & 10.128 \\
\hline
\end{tabular}

Table 7. Investing Cash Flows (in thousand USD) (Advanced)

\begin{tabular}{|c|c|c|c|c|c|c|}
\hline \multirow[t]{2}{*}{ No } & \multirow{2}{*}{ Component } & \multicolumn{5}{|c|}{ to-year } \\
\hline & & 0 & 1 & 10 & 20 & 30 \\
\hline & 7. General & & 3.217 & 4.401 & 5,199 & 6.756 \\
\hline & 8. Insurance & & 980 & 1,340 & 1,583 & 2,057 \\
\hline & Total Flow Out Before Tax & 173.073 & 44.098 & 57.103 & 67.943 & 81.451 \\
\hline $\mathbf{C}$ & Income Before Tax & & 43,400 & 94.057 & $\begin{array}{ll}199.197 \\
\end{array}$ & 341.897 \\
\hline & 1. Taxes $(25 \%)$ & & 10.850 & 23.514 & 49.799 & 85.474 \\
\hline & Total Flow Out After Tax & & 54.948 & 80.617 & 117.743 & 166.925 \\
\hline & $\begin{array}{l}\text { Flow Out for Calculating } \\
\text { IRR }\end{array}$ & 173.073 & 45.115 & 69.113 & 107.910 & 156.797 \\
\hline $\mathbf{D}$ & Net flow (NCF) & & 32.550 & 70.543 & 149.398 & 256.423 \\
\hline $\mathbf{E}$ & $\begin{array}{l}\text { CASH FLOW FOR } \\
\text { COMPUTING IRR }\end{array}$ & (173.073) & 42.383 & 82.047 & 159.231 & 266.551 \\
\hline & Discount Factor $(15 \%)$ & $1: 00$ & 0.87 & $0: 25$ & $0: 06$ & $0: 02$ \\
\hline & Present Value & \begin{tabular}{|l|}
$(173.073)$ \\
\end{tabular} & 36.855 & 20.281 & 9.729 & 4.026 \\
\hline $\mathbf{F}$ & cummulative & \begin{tabular}{|l|}
$(173.073)$ \\
\end{tabular} & (136.218) & 93.390 & 239.924 & 303.376 \\
\hline
\end{tabular}

Valuation of investments is made by two factors: the Internal Rate of Return (IRR) and Profitability Index (PI). The results of the analysis of investment criteria shown in Table 8.

Table 8. Analysis of Investment Criteria

\begin{tabular}{|c|c|c|}
\hline df & IRR & PI \\
\hline $10 \%$ & $31.01 \%$ & 4.71 \\
\hline $12 \%$ & $31.01 \%$ & 3.73 \\
\hline $15 \%$ & $31.01 \%$ & 2.75 \\
\hline $20 \%$ & $31.01 \%$ & 1.83 \\
\hline $25 \%$ & $31.01 \%$ & 1.34 \\
\hline
\end{tabular}

Based on the calculation of investment criteria, investment declared eligible for all the criteria. This number is eligible enough if compared on the feasibility study of Port of Tg. Bulupandan and Socah which respectively only can get the value of IRR of $6.9 \%$ and $6.5 \%$ in [2] or the feasibility study of Baubau Port which the IRR value is $14.81 \%$ in [8].

\section{Study of Sensitivity Analysis}

The sensitivity analysis was performed to assess the robustness level of investment on changes in the factors that influence it. In this case the sensitivity analysis will be carried out by a factor of costs and benefits. This is done to see the extent to which level the investment will be profitable to conditions less favorable. The sensitivity analysis will be performed using 6 scenarios as shown in Table 9. 
Table 9. Sensitivity Analysis

\begin{tabular}{|c|c|c|c|}
\hline \multirow{2}{*}{ No. } & \multirow{2}{*}{ Parameter Changes } & \multicolumn{2}{|c|}{ df $=\mathbf{1 5 \%}$} \\
\cline { 3 - 4 } & & IRR & PI \\
\hline 1 & Costs up 20\%, benefit fixed & $28.68 \%$ & 2.52 \\
\hline 2 & Costs fixed, benefits down 20\% & $23.99 \%$ & 1.97 \\
\hline 3 & Costs up 20\%, benefit down 20\% & $21.75 \%$ & 1.74 \\
\hline 4 & Costs up 30\%, benefit fixed & $27.54 \%$ & 2.41 \\
\hline 5 & Cost fixed, benefits down 30\% & $20: 45 \%$ & 1.58 \\
\hline 6 & Costs up 30\%, benefits down 30\% & $17: 15 \%$ & 1.23 \\
\hline
\end{tabular}

Based on Table 9 can be concluded that all the investment criteria that are in decent value by screenplay 6 with $\mathrm{df}=15 \%$ of the cost up $30 \%$ and down $20 \%$ benefit. This suggests investment will still be profitable even if the decline in the value of the benefits and operating costs rise by $30 \%$. This number is considered good since another study about ports in Indonesia mostly only feasible if the fluctuation of changes is below $20 \%$ [2] \& [8].

\section{CONCLUSION}

Based on the analysis of the discussion that has been done it can be concluded that financially, Belawan Port Flow development project feasible. This is evident from the forecast results showing an increase every year. Productivity port is also expected to run smoothly because based on calculations, future productivity conditions do not exceed the standard $70 \%$. Results of testing the benefits of the project to see the difference in benefits between the state of the project and without the project showed decent results with EIRRs $>$ discount factor and PI $>1$ discount factor $=12 \%$. Financial analysis also gives good value with IRR $>$ discount factor and PI $>1$ discount factor $=15 \%$. The sensitivity test is done under extreme conditions with an increase in cost of $30 \%$ when the benefits down $30 \%$ and the results also showed a decent index. The results of this calculation indicate that the investment is feasible.

\section{Acknowledgment}

The authors gratefully acknowledge to my student Ratih Sulastri for her efforts to collect data for the purposes of this research.

\section{References}

[1] The Ministry of Transport of the Republic of Indonesia. 2012. Indonesia Belawan Port Master Plan. Indonesia.

[2] JICA Team. 2007. The Study for Development of the Greater Surabaya Metropolitan Ports in the Republic of Indonesia (Final Report). Surabaya: PT. Pelindo III.

[3] Bapennas. 2015. Toll Marine Concepts and Implementation 2015-2019. Indonesia. MoT: Indonesian.

[4] Harrison, Roberts and Miguel Figliozzi. 2001. Impacts of Container Ship Size, Service Routers, and Demand on Texas Gulf Ports. Texas Department of Transportation and the University of Texas: Austin.

[5] Kullinane, Kevin and Mahim Khanna. 2005. Economies of Scale in Large Container Ships. Journal of Transport Economics and Policy. Volume 3, Part 2.

[6] Azizah, Fitri Alwi. 2015. Technical and Financial Feasibility Analysis on Industrial Rubber Processing Small Scale in Musi Rawas South Sumatra (Case Study on Plant DMK and Rubber Processing Unit Subur Farmer Group). Malang: Brawijaya University.

[7] Hermawati. 2011. Financial and Economic Feasibility Analysis of the Port of Central Sumba. Konstruksia Journal Volume 3 No 1 December 2011. Central Sumba: Konstruksia.

[8] The Ministry of Planning / Bapennas. 2015. Preparation of a Transaction Document Public-Private Partnership Projects Port Baubau, Southeast Sulawesi: pre-feasibility study Assessment Report (Final Business Case). Southeast Sulawesi.

[9] Local Government Batang. 2005. Commercial Port Development Feasibility Study Batang. Central Java.

[10] PT. Pelindo I. 2013. Decree of the Board of Directors of PT Pelabuhan Indonesia I (Persero): Calculation Manual and Traffic Operational Performance Reporting Revenues in Environmental Production PT. Pelabuhan Indonesia I (Persero). North Sumatra.

[11] Ibrahim, Yacob. 2003. Business Feasibility Study. Revised Edition. Cet.2, Jakarta: PT Asdi Mahasatya.

[12] Public and Private Infrastructure Investment Management Center (PIMAC). 2008. General Guidelines for the Preliminary Feasibility Study. Fifth edition. South Korea

[13] Sudiarsa Made. 2011. Analysis of Economic Development of Port Amed Karangasem. Bali: Bali State Polytechnic.

[14] Minister of Transport of the Republic of Indonesia. 2015. PM 51 in 2015; Operation of Seaports. Indonesia.

[15] Simarmata, Frins Apul. Investment Feasibility Study 2015. Procurement of Equipment PT Pelabuhan Indonesia IV (Persero) in Makassar.: Denpasar: Udayana University. 